\title{
DESKRIPSI KEGIATAN BUDIDAYA TOGA BERBASIS URBAN FARMING SERTA ASPEK KENDALA YANG DIHADAPI: SUATU KASUS TOGA KUNYIT DI KELURAHAN RANCABOLANG, KECAMATAN GEDEBAGE, KOTA BANDUNG
}

\author{
DESCRIPTION OF TOGA CULTIVATION ACTIVITIES BASED ON URBAN \\ FARMING AND CONSTRAINTS ASPECTS: A CASE OF TURMERIC IN \\ RANCABOLANG VILLAGE, GEDEBAGE DISTRICT, BANDUNG CITY
}

\author{
Elly Rasmikayati ${ }^{1}$, Anton Eisa Putra ${ }^{1}$, Bobby Rachmat Saefudin*2 \\ ${ }^{1}$ Fakultas Pertanian, Universitas Padjadjaran, Jl. Ry Bandung-Sumedang KM.21 Jatinangor, 45363 \\ ${ }^{2}$ Fakultas Pertanian, Ma'soem University, J1. Raya Cipacing No. 22 Jatinangor, 45363 \\ *E-mail corresponding: bobbyrachmat@masoemuniversity.ac.id
}

(Diterima 10-1-2021; Disetujui 18-1-2021)

\begin{abstract}
ABSTRAK
Kelurahan Rancabolang Kecamatan Gedebage Kota Bandung merupakan salah satu kelurahan yang sudah menjalankan budidaya tanaman TOGA berbasis urban farming. Akan tetapi, program tersebut belum berjalan optimal. Penelitian ini bertujuan untuk mengetahui bagaimana deskripsi pelaksanaan kegiatan budidaya tanaman TOGA berbasis urban farming serta kendala yang dialami masyarakat selama pelaksanaannya. Data dan informasi yang diperoleh dianalisis menggunakan statistik deskriptif. Hasil penelitian menunjukkan kegiatan budidaya TOGA di Kelurahan Rancabolang sampai saat ini belum mampu untuk sampai ke tahap produksi untuk dapat dimanfaatkan secara ekonomis. Hal ini dikarenakan sebagian besar hasil panen hanya dimanfaatkan oleh anggota kelompok PKK, dan kegiatan panen tidak dilakukan secara rutin ketika sudah sampai masa panen. Adapun 4 aspek kendala yang dibahas dalam penelitian ini. Pada aspek kendala budidaya TOGA, lahan yang terbatas menjadi kendala utama dan kendala lainnya yaitu kebutuhan bibit. Pada aspek kendala panen, proses panen yang tidak terjadwal dan tidak rutin menjadi kendala utamanya. Pada aspek pemasaran, jumlah produksi yang masih sedikit menjadi kendala utamanya. Pada aspek organisasi, partisipasi anggota menjadi kendala utama dan kendala lainnya adalah kegiatan rapat rutin untuk membahas Budidaya TOGA.
\end{abstract}

Kata kunci: budidaya, TOGA, kunyit, urban farming, kendala, panen, pemasaran, organisasi

\begin{abstract}
Rancabolang Village, Gedebage Subdistrict, Bandung City is one of the sub-districts which in several RWs has carried out the cultivation of TOGA plants based on urban farming. However, in reality, the program has not run optimally because it has not been able to absorb all members to be able to play an active role. This study aims to determine the description of the implementation of the TOGA plant cultivation activity based on urban farming and the obstacles experienced by the community during its implementation. The data and information obtained is analyzed using descriptive statistics. The results showed that TOGA cultivation activities in Rancabolang Village have not been able to get to the production stage to be used economically. This is because most of the harvest is only used by PKK group members and harvesting activities are not carried out routinely when it reaches harvest time. There are 4 aspects of the constraints discussed in this study. In terms of the constraints on TOGA cultivation, limited land is the main obstacle and another obstacle is the need for seeds. In the aspect of harvest constraints, unscheduled and irregular harvesting processes are the main obstacles. On the marketing aspect, the small amount of production is the main obstacle. In the organizational aspect, member participation is the main obstacle and another obstacle is the routine meeting activities to discuss TOGA cultivation.
\end{abstract}

Keywords: cultivation, TOGA, turmeric, urban farming, constraints, harvest, marketing, organization 


\section{PENDAHULUAN}

Dalam konteks optimalisasi lahan atau pengembangan wilayah, dimensi ruang mempunya arti yang penting bagi individu dan masyarakat (Riyadi, 2012). Dimensi ruang menjadi penting karena ketersediaannya yang semakin langka dan terbatas. Ruang adalah wadah tempat manusia dan makhluk hidup lainnya hidup dan melakukan kegiatan serta memelihara kelangsungan hidupnya. Ruang mencakup lahan dengan berbagai sumberdaya yang ada di atas maupun di dalamnya (Rasmikayati dkk., 2019). Berkaitan dengan ketersediaannya yang semakin terbatas, perlu tindakan yang tepat dalam mengoptimalisasi lahan yang yang belum diusahakan. Berikut ditampilkan data mengenai lahan yang belum diusahakan di Provinsi Jawa Barat (Tabel 1).

Tabel 1. Luas Lahan yang Sementara Tidak Diusahakan Menurut Kota di Provinsi Jawa Barat (Hektar), Tahun 2012-2014

\begin{tabular}{|c|c|c|c|}
\hline $\begin{array}{l}\text { Kota } \\
\text { City }\end{array}$ & $\begin{array}{c}\text { Tahun } \\
2012\end{array}$ & $\begin{array}{c}\text { Tahun } \\
2013\end{array}$ & $\begin{array}{c}\text { Tahun } \\
2014\end{array}$ \\
\hline Bogor & 27 & 22 & 26 \\
\hline Sukabumi & - & 39 & - \\
\hline Bandung & 118 & 88 & 37 \\
\hline Cirebon & 17 & 20 & 20 \\
\hline Bekasi & - & - & - \\
\hline Depok & 465 & 383 & 341 \\
\hline Cimahi & - & - & - \\
\hline Tasikmalaya & 15 & 25 & 65 \\
\hline Banjar & - & - & - \\
\hline Jumlah/Total & 642 & 577 & 489 \\
\hline
\end{tabular}

Tabel 1 menggambarkan bagaimana perkembangan jumlah luas lahan yang sementara tidak diusahakan di Provinsi Jawa Barat. Di Kota Bandung dapat dilihat pada tahun 2012 sampai dengan tahun 2014 terdapat penurunan jumlah luas lahan yang sementara tidak diusahakan. Penurunan terjadi salah satunya dikarenakan berbagai komunitas berkebun yang mulai berkembang di Kota Bandung. Pemanfaatan lahan tidur untuk kegiatan urban farming menjadi pemicu untuk kemudian kegiatan ini dijadikan sebuah program oleh pemerintahan Kota Bandung pada tahun 2014. Dampak yang dirasakan pun cukup baik hingga $70 \%$ warga di Kota Bandung pada setiap tingkat RW sudah melakukan kegiatan ini. Oleh karena itu, pemanfaatan lahan untuk kegiatan urban farming perlu dilakukan secara kontinu.

Kegiatan urban farming pada zaman dengan perkembangan yang pesat ini merupakan suatu kegiatan yang penting. Pelaksanaan kegiatan urban farming di berbagai daerah juga diharapkan dapat terlaksana dengan baik, khususnya di kawasan perkotaan. Hal ini tidak terlepas dari proses alih fungsi lahan yang berkembang dengan cepat di perkotaan. Terkait hal tersebut, proses pelaksanaan kegiatan urban farming 
mulai dari ruang lingkup dengan kelompok lebih kecil seperti RW sudah sepatutnya didukung agar tetap berjalan. Kelurahan Rancabolang Kecamatan Gedebage Kota Bandung merupakan salah satu kelurahan yang di beberapa RW sudah menjalankan kegiatan ini. Melalui kelompok PKK yang menjalankan kegiatan urban farming di setiap RW, pelaksanaan kegiatan dengan menanam tanaman Toga (Tanaman Obat Keluarga) diharapkan mampu diaplikasikan oleh setiap RW. Hal ini tentunya akan sangat menguntungkan ketika kegiatan tersebut mampu untuk diusahakan secara komersial.

Pada kenyataannya, proses menanam tanaman toga berbasis urban farming di Kelurahan Rancabolang belum dapat dikatakan optimal. Hal ini dapat dilihat dari proses partisipasi masyarakat yang dilakukan di masingmasing RW. Dari 10 RW yang ada di sana, hanya setengahnya atau 5 RW yang sudah menjalankan kegiatan urban farming melalui kelompok PKK yang ada. Tidak semua RW melakukan program kegiatan urban farming yang dicanangkan oleh kelurahan setempat. Hanya beberapa RW saja yang sudah mampu membudidayakan tanaman
TOGA untuk kemudian diusahakan secara komersial.

Berdasarkan harapan dan kenyataan yang ada, akan diteliti bagaimana proses pelaksanaan dan kendala dalam pelaksanaan budidaya tanaman toga berbasis urban farming di Kelurahan Rancabolang tan Gedebage Kota Bandung.

\section{METODE PENELITIAN}

\section{Objek dan Tempat Penelitian}

Objek dari penelitian ini yaitu proses pelaksanaan dan kendala yang dihadapi masyarakat dalam pelaksanaan budidaya tanaman toga jenis kunyit berbasis urban farming. Tempat penelitian ditentukan secara sengaja (purposive) yaitu Kelurahan Rancabolang, Kecamatan Gedebage, Kota Bandung dengan mempertimbangkan tempat penelitian ini merupakan salah satu percontohan kegiatan budidaya tanaman toga berbasis urban farming yang pernah cukup aktif.

\section{Desain Penelitian}

Desain penelitian yang digunakan adalah desain kuantitatif yang kemudian dapat ditarik kesimpulan dengan melakukan uji statistik. Metode penelitian kuantitatif merupakan salah satu jenis 
penelitian yang spesifikasinya sistematis, terencana, dan terstruktur dengan jelas sejak awal hingga pembuatan desain penelitiannya. Definisi lain menyebutkan penelitian kuantitatif adalah penelitian yang banyak menuntut penggunaan angka, mulai dari pengumpulan data, penafsiran terhadap data tersebut, serta penampilan dari hasilnya. Demikian pula pada tahap kesimpulan penelitian akan lebih baik bila disertai dengan gambar, tabel, grafik, atau tampilan lainnya.

\section{Variabel Penelitian}

Saputra dkk (2018) menyatakan bahwa variabel merupakan konsep yang mempunyai bermacam-macam nilai. Dalam penelitian ini terdapat 2 konsep utama sebagai acuan untuk melakukan penelitian, yaitu:

1. Pelaksanaan budidaya tanaman TOGA Konsep ini menjelaskan mengenai proses pelaksanaan kegiatan urban farming, yaitu budidaya tanaman TOGA yang dilakukan oleh responden. Variabelvariabel dalam konsep ini diantaranya: 1) Komoditas yang Diusahakan; 2) Persiapan dan Pengolahan Tanah; 3) Persiapan Bibit; 4) Penanaman; 5) Pemeliharaan; 6) Pemanenan, Pemasaran, dan Biaya Produksi.
2. Kendala dalam budidaya tanaman TOGA Urban Farming

Konsep ini menjelaskan mengenai kendala responden dalam kegiatan urban farming selama melakukan rapat dalam kelompok dan pelaksanaan budidaya tanaman TOGA yang dilakukannya. Variabel-variabel dalam konsep ini diantaranya: 1) Kendala Budidaya; 2) Kendala Panen; 3) Kendala Pemasaran; dan 4) Kendala Organisasi.

\section{Jenis dan Sumber Data}

Sumber data yang digunakan dalam penelitian ini terdiri atas data primer dan data sekunder, yaitu:

1. Data Primer

Menurut Narimawati (2007), data primer merupakan data yang diambil dari responden secara langsung yang dikumpulkan melalui survey lapangan dengan menggunakan teknik tertentu. Data primer diperoleh dari hasil observasi, pengamatan, dan wawancara melalui pengisian kuesioner kepada kelompok PKK Kelurahan Rancabolang Kecamatan Gedebage.

2. Data Sekunder

Menurut Narimawati (2007), data sekunder merupakan data penunjang yang digunakan untuk mendukung penelitian ini meliputi informasi 
mengenai karakteristik organisasi, serta penelitian terdahulu yang berhubungan dengan objek data yang akan diteliti. Data penunjang tersebut juga dapat diperoleh dari studi literatur kepustakaan, dokumen instansi dan lembaga terkait, jurnal dan media internet yang berhubungan dengan penelitian.

\section{Populasi, Sampel dan Sampling}

Populasi dalam penelitian ini yaitu seluruh anggota kelompok PKK Kelurahan Rancabolang Kecamatan Gedebage Kota Bandung sebanyak 240 orang. Menurut Slovin dalam Nugraha (2018) menentukan sampel dapat digunakan rumus sebagai berikut:

$n=\frac{N}{1+N(e)^{2}}$

Keterangan :

$\mathrm{n}=$ jumlah sampel

$\mathrm{N}=$ ukuran populasi

$\mathrm{e}=$ toleransi terjadinya error $(15 \%)$

Berdasarkan perhitungan dari rumus tersebut didapat jumlah sampel sebanyak 25 orang. Penentuan sampel menggunakan teknik simple random sampling agar setiap anggota populasi memiliki kesempatan yang sama untuk dipilih, sehingga sampel yang didapat dapat mewakili populasi.

\section{Rancangan Analisis Data}

Statistika deskriptif digunakan sebagai alat analisis data dalam penelitian ini. Pembahasan yang berkaitan dengan statistika deskriptif meliputi tabel distribusi frekuenai, serta berbagai grafik dan diagram.

\section{HASIL DAN PEMBAHASAN}

\section{Deskripsi Pelaksanaan Kegiatan Budidaya Tanaman TOGA Berbasis Urban Farming}

\section{Komoditas yang Diusahakan}

Komoditas yang diusahakan di tempat penelitian yaitu TOGA (Tanaman Obat Keluarga). Terdapat 4 komoditas TOGA yang masih banyak diusahakan di tempat penelitian yang diteliti, yaitu kunyit, serai, seledri, dan lidah buaya. Banyaknya responden yang mengusahakan TOGA komoditas tersebut dapat dilihat pada Gambar 1.

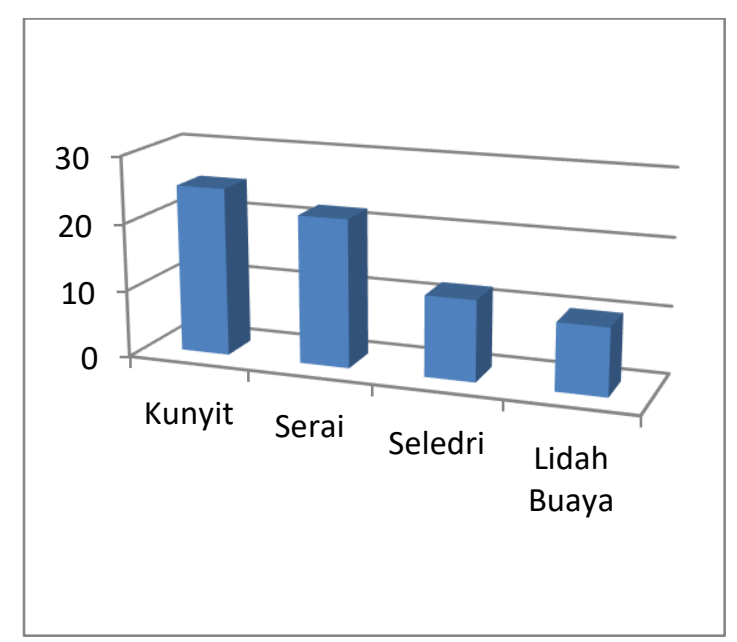

Gambar 1. Komoditas TOGA yang Diusahakan 
Berdasarkan diagram Gambar 1, dari 25 responden yang ada dapat dilihat sebanyak 25 orang $(100 \%)$ membudidayakan TOGA jenis kunyit, 22 orang (88\%) membudidayakan TOGA jenis serai, 12 orang $(48 \%)$ membudidayakan TOGA jenis seledri, dan 10 orang $(40 \%)$ membudidayakan TOGA jenis lidah buaya. Dari 4 komoditas yang ada, dapat dilihat bahwa modus komoditas TOGA yang diusahakan adalah tanaman kunyit. Berdasarkan hal tersebut, maka komoditas kunyit akan menjadi komoditas utama yang akan dianalisis pada penelitian ini.

\section{Persiapan dan Pengolahan Tanah}

Proses persiapan dan pengolahan tanah pada budidaya TOGA dibutuhkan sebelum memulai kegiatan menanam TOGA. Lahan yang sesuai dengan karakteristik tanaman akan mempengaruhi proses pertumbuhan dan perkembangan TOGA.

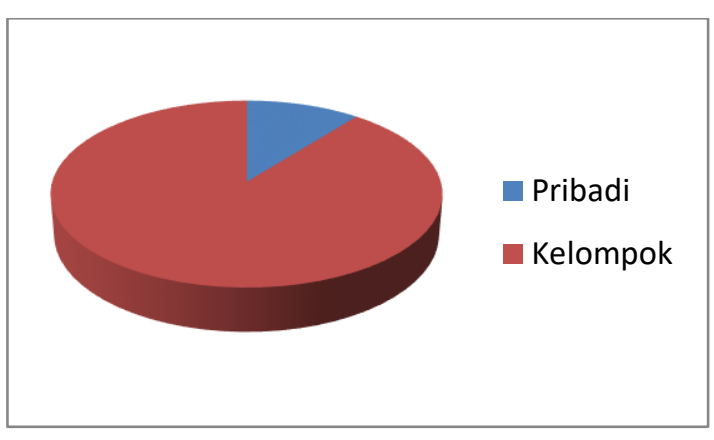

Gambar 2. Status Lahan TOGA
Berdasarkan Gambar 2, dari 25 responden di atas seluruhnya (100\%) membudidayakan TOGA kunyit pada lahan kelompok. Sebanyak 3 orang (12\%) membudidayakan TOGA kunyit juga pada lahan miliknya sendiri. Dapat dilihat dari 25 responden, baru 3 orang yang mampu membudidayakan TOGA kunyit pada lahan miliknya sendiri. Hal ini dikarenakan lahan milik mereka memiliki ruang yang cukup untuk dimaanfaatkan untuk kegiatan urban farming. Lahan kelompok yang digunakan untuk budidaya TOGA kunyit ada 2 lahan. Satu lahan berada di RW 7 dengan luas lahan sebesar \pm 50 meter $^{2}$ dan satu lahan lainnya berada di RW 9 dengan luas lahan sebesar \pm 30 meter $^{2}$. Tanah yang digunakan untuk melakukan budidaya TOGA kunyit adalah tanah lembang sebanyak 1 colt/truk dengan pupuk organik dan kimia masing- masing sebanyak $150 \mathrm{~kg}$. Proses persiapan dan pengolahan tanah sendiri memakan waktu dua sampai tiga hari.

\section{Persiapan Bibit}

Proses persiapan bibit pada budidaya TOGA dilakukan setelah lahan selesai disiapkan. Pada proses persiapan bibit, dari 25 responden seluruhnya (100\%) mendapatkan bibit siap pakai dari pemerintah setempat (Kelurahan 
Rancabolang). Oleh karena itu, pada proses ini responden tidak perlu melakukan proses persemaian, dll. Karena bibit tersebut sudah disediakan oleh pihak kelurahan. Setiap responden mendapatkan 3 sampai 5 bibit dari setiap komoditas yang diusahakan. Media tanam yang digunakan yaitu pot-pot dengan ukuran berbagai macam yang sudah disediakan juga oleh pihak kelurahan.

\section{Penanaman}

Proses penanaman pada budidaya TOGA jenis kunyit dilakukan dengan memperhatikan jumlah lubang tanam dan bibit yang dimasukkan ke dalam setiap lubang tanam.. Pada proses penanaman, dari 25 responden seluruhnya (100\%) menanam TOGA kunyit sebanyak 3 lubang tanam dengan satu lubang tanam diisi oleh satu bibit. Tanaman kunyit ditanam pada pot yang sudah disediakan oleh pihak kelurahan setempat. Proses penanaman memakan waktu satu sampai dua hari.

\section{Pemeliharaan}

Proses pemeliharaan pada budidaya TOGA jenis kunyit perlu dilakukan secara rutin untuk menunjang hasil panen yang baik. Pemeliharaan yang dilakukan terdiri atas pemupukan, penyiraman, penyiangan, pengendalian gulma, pembumbunan, pengendalian hama dan penyakit tanaman, serta pemangkasan.

Intensitas pemeliharaan TOGA kunyit yang dilakukan dalam sekali musim tanam, dari 25 responden yang ada, seluruhnya (100\%) melakukan setiap jenis pemeliharaan sebanyak 4 kali dalam sebulan. Hal ini dikarenakan pemeliharaan ini sudah diarahkan oleh pemerintahan setempat melalui kegiatan penyuluhan "Menanam TOGA".

\section{Pemanenan, Pemasaran, dan Biaya}

\section{Produksi}

Proses pemanenan pada budidaya TOGA jenis kunyit di tempat penelitian masih dilakukan secara subsisten. Dari 25 responden yang ada, didapatkan informasi bahwa proses panen dilakukan ketika responden membutuhkan TOGA kunyit yang dibudidayakan. Panen dilakukan oleh responden yang saat itu membutuhkan kunyit untuk dimafaatkan olehnya. Dalam sekali musim tanam (3 bulan), ketika sudah memasuki musim panen, responden yang membutuhkan TOGA kunyit bisa langsung memanen kunyit di lahan kelompok yang sudah disediakan. Jumlah panen yang biasanya diambil oleh responden hanya sedikit berkisar antara 2 sampai 5 buah tanaman kunyit sekali panen. Jumlah responden yang melakukan panen pun tidak terlalu 
banyak. Dalam sekali proses panen, ratarata responden yang melakukan panen antara 5 sampai 8 orang atau kurang dari setengahnya. Hal ini dikarenakan responden yang melakukan panen hanyalah responden yang membutuhkan TOGA kunyit tersebut.

Pada proses pemasaran, TOGA jenis kunyit yang diteliti oleh peneliti belum berjalan. Sebagian besar hasil panen yang ada dimaanfaatkan oleh hampir seluruh responden untuk kebutuhan pribadi. Ada yang digunakan untuk bahan tambahan bumbu penyedap atau dimanfaatkan sebagai obat herbal.

Biaya produksi yang dibutuhkan dalam melakukan kegiatan urban farming TOGA di tempat penelitian hanya sebatas alat pertanian saja. Biaya untuk tanah, pupuk, dan bibit didanai oleh pihak kelurahan setempat. Dalam sekali musim tanam, biaya yang digunakan untuk membeli tanah yaitu Rp 600.000,- untuk tanah sebanyak 1 colt/1 truck, pupuk dan bibit sebesar Rp 1.200.000,-. Alat pertanian yang digunakan diantaranya pacul, arit, dan koret. Harga pacul yang dikeluarkan, yaitu berkisar antara $\mathrm{Rp}$ 45.000.- sampai Rp 160.000,- dengan jumlah barang 1 sampai 2 buah setiap responden. Harga arit yang dikeluarkan, yaitu berkisar antara Rp 30.000,- sampai
Rp 80.000,- dengan jumlah barang 1 sampai 2 buah setiap responden. Harga koret yang dikeluarkan, yaitu berkisar antara Rp 25.000.- sampai Rp 65.000,dengan jumlah barang 1 sampai 2 buah setiap responden. Gambaran biaya usahatani seperti ini termasuk dalam kategori usahatani skala kecil (Rasmikayati dkk., 2020).

Biaya yang dikeluarkan dalam kegiatan produksi kunyit di Kelurahan Rancabolang masih sulit untuk dihitung dalam bentuk analisis usahatani. Hal ini dikarenakan kurang transparannya danadana yang dikeluarkan Kelurahan Rancabolang guna mendukung Program Penanaman TOGA. Adapun perhitungan analisis usahatani yang optimum dimasukkan ke dalam karya tulis ilmiah ini, guna menunjang informasi budidaya kunyit yang baik dan benar. Berikut analisis usahatani kunyit dengan teknologi budidaya anjuran Balitro (Balai Penelitian Tanaman Obat dan Aromatika) pada luasan 1 hektar (Tabel 2).

Tabel 2 menjelaskan hasil usahatani budidaya kunyit dengan teknologi budidaya anjuran Balitro pada luasan 1 hektar. Dapat dilihat pada Tabel 2 bahwa produktivitas kunyit pada lahan luasan 1 hektar yaitu sejumlah 18 ton/Ha dengan harga jual Rp. 2000,- /kg. Dengan total 
produksi dan harga jual tersebut nantinya akan menghasilkan keuntungan sebanyak Rp. 10.850.000,- dalam sekali musim tanam atau akan mampu menghasilkan setelah tanaman berumur $10-12$ bulan sejak tanam. Menurut Amelia dkk. (2020), pendapatan petani yang memgikiti SOP lebih baik dari pada yang tidak mengikuti. Lebih lanjut, menurut Wati dkk. (2020), pendapatan usahatani berhubungan dengan penerapan SOP oleh petani.

Tabel 2. Hasil Usahatani Kunyit berdasarkan anjuran Balitro pada Luasan 1 Ha

\begin{tabular}{|c|c|c|c|c|}
\hline No. & Uraian & $\begin{array}{l}\text { Volume } \\
\text { fisik }\end{array}$ & $\begin{array}{l}\text { Harga satuan } \\
\text { (Rp) }\end{array}$ & $\begin{array}{l}\text { Total } \\
(\mathrm{Rp})\end{array}$ \\
\hline \multicolumn{5}{|c|}{ I. $\quad$ Pengeluaran Upah } \\
\hline & 1. Pengolahan Tanah I & $90 \mathrm{HOK}$ & $15.000,-$ & $1.350 .000,-$ \\
\hline & 2. Pengolahan Tanah II & $90 \mathrm{HOK}$ & $15.000,-$ & 1.350.000,- \\
\hline & 3. Pemupukan dasar & $30 \mathrm{HOK}$ & $15.000,-$ & $450.000,-$ \\
\hline & 4. Tanam & $60 \mathrm{HOK}$ & $15.000,-$ & $900.000,-$ \\
\hline & 5. Pemeliharaan & $100 \mathrm{HOK}$ & $15.000,-$ & 1.500.000,- \\
\hline & 6. Panen & $90 \mathrm{HOK}$ & $15.000,-$ & $1.350 .000,-$ \\
\hline & 7. Prosesing hasil panen & $60 \mathrm{HOK}$ & $15.000,-$ & $900.000,-$ \\
\hline \multicolumn{2}{|r|}{ Total Upah } & & & $7.800 .000,-$ \\
\hline \multicolumn{5}{|c|}{ II. Pengeluaran Bahan } \\
\hline & 1. Benih & $1000 \mathrm{~kg}$ & $3.000,-$ & $3.000 .000,-$ \\
\hline & 2. Pupuk kandang & 20 ton & $80.000,-$ & 1.600.000,- \\
\hline & 3. Urea & $100 \mathrm{~kg}$ & $1.750,-$ & $1.750 .000,-$ \\
\hline & 4. SP 36 & $200 \mathrm{~kg}$ & $1.750,-$ & $3.500 .000,-$ \\
\hline & 5. $\mathrm{KCl}$ & $200 \mathrm{~kg}$ & $3.000,-$ & $6.000 .000,-$ \\
\hline & 6. Karung plastik & $750 \mathrm{lbr}$ & $2.000,-$ & $1.500 .000,-$ \\
\hline \multicolumn{2}{|r|}{ Total Bahan } & & & 17.350.000,- \\
\hline \multicolumn{2}{|c|}{ Total Pengeluaran (I + II) } & & & $25.150 .000,-$ \\
\hline \multicolumn{5}{|c|}{ III. $\quad$ Pendapatan Bruto } \\
\hline \multicolumn{2}{|c|}{ Produksi rimpang segar } & $18.000 \mathrm{~kg}$ & $2.000,-$ & $36.000 .000,-$ \\
\hline IV. & Keuntungan & & & 10.850.000,- \\
\hline
\end{tabular}

\section{Deskripsi Kendala yang Dihadapi Masyarakat pada Kegiatan Budidaya Tanaman TOGA Berbasis Urban Farming}

\section{Kendala Budidaya}

Kendala budidaya yaitu kendala yang ditemukan selama responden melakukan budidaya TOGA jenis kunyit di lapangan. Gambar 3 menjelaskan mengenai kendala budidaya TOGA yang ditemukan di lapangan.

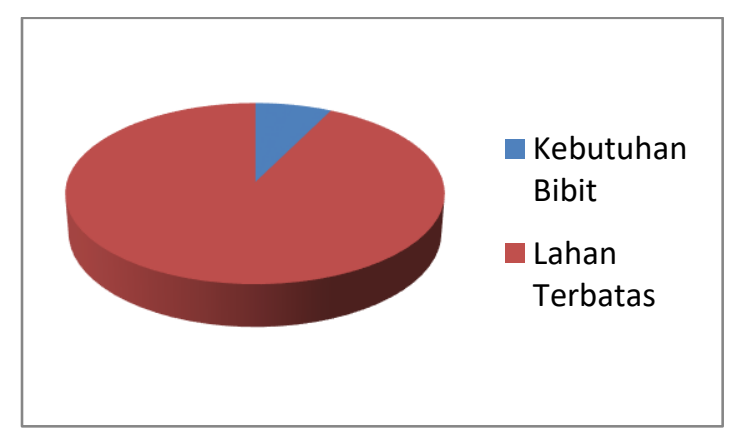

Gambar 3. Kendala Budidaya TOGA 
Berdasarkan Gambar 3, dari 25 responden yang ada, terdapat 25 orang atau seluruhnya (100\%) yang mengemukakan bahwa lahan yang terbatas menjadi kendala dalam membudidayakan TOGA. Sebanyak 2 orang (8\%) mengemukakan bahwa kebutuhan bibit juga menjadi kendala dalam membudidayakan TOGA. Dapat dilihat dari hasil yang ditemukan di lapangan bahwa lahan yang terbatas merupakan modus atau kendala utama dalam membudidayakan TOGA. Beberapa sample dari responden mengemukakan bahwa tidak semua rumah tangga memiliki lahan yang memadai untuk membudidayakan TOGA. Lahan yang ada cenderung memiliki ruang yang sempit dan sulit untuk dimanfaatkan untuk melakukan kegiatan urban farming. Hal ini disebabkan pemilik rumah tidak memiliki waktu yang cukup untuk memelihara pekarangan rumahnya karena pekerjaan sehari-harinya.

\section{Kendala Panen}

Kendala panen yaitu kendala yang ditemukan selama responden melakukan kegiatan panen. Data didapatkan dari item pertanyaan yang diajukan pada dimensi kendala panen. Berdasarkan 25 responden yang ada, rata-rata jumlah tanaman kunyit yang mati dalam sekali musim tanam adalah 1 sampai 2 tanaman. Dari beberapa responden yang ada, kendala yang ditemukan yaitu proses panen yang dilakukan secara tidak terjadwal. Tanaman kunyit dipanen saat responden merasa perlu untuk menggunakan tanaman kunyit tersebut. Hal ini mengakibatkan tanaman yang sudah lama tidak dipanen akan semakin membusuk karena asupan nutrisi yang berkurang ketika sudah memasuki masa panen.

\section{Kendala Pemasaran}

Faktor pemasaran sering kali menjadi kendala utama dalam agribisnis (Rasmikayati dkk., 2020). Kendala pemasaran yaitu kendala yang ditemukan selama responden melakukan kegiatan budidaya TOGA jenis kunyit. Data didapatkan dari item pertanyaan yang diajukan pada dimensi kendala pemasaran. Berdasarkan 25 responden yang ada, seluruhnya (100\%) mengemukakan bahwa jumlah produksi yang masih sedikit merupakan kendala utama pada proses pemasaran. Jumlah produksi dalam sekali musim tanam yang belum dapat dikontrol (diatur pola tanam) mengakibatkan jumlah produksi yang didapatkan tidak bisa untuk diprediksi. Salah satu hal yang berdampak pada 
proses pemasaran pada kegiatan on farm yaitu proses panen yang tidak terjadwal. Hal ini juga yang mengakibatkan saat ini kegiatan urban farming TOGA jenis kunyit di tempat penelitian yang masih sulit untuk dikomersialkan. Saat ini, hasil panen yang didapat hampir seluruhnya digunakan untuk konsumsi pribadi responden.

\section{Kendala Organisasi}

Kendala organisasi merupakan kendala yang paling banyak ditemukan di dalam organisasi Kelompok PKK di tempat penelitian.

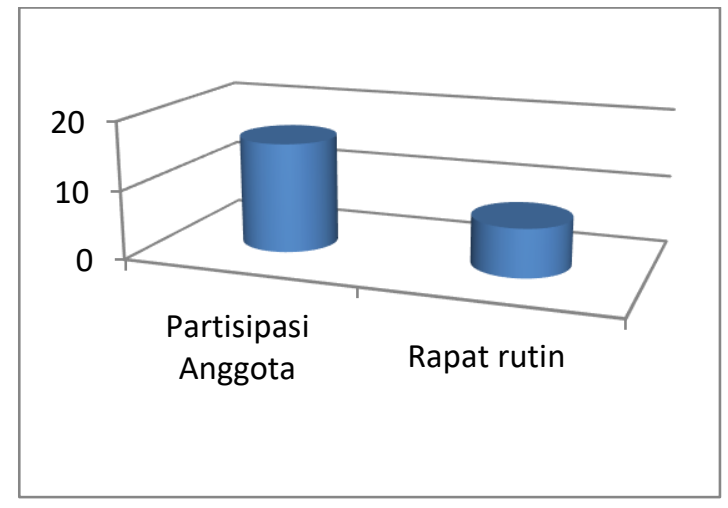

Gambar 4. Kendala Organisasi

Gambar 4 menunjukkan kendala organisasi yang ditemukan di lapangan saat responden melakukan kegiatan urban farming tanaman kunyit. Berdasarkan diagram di atas, dari 25 responden yang ada, terdapat 16 orang (64\%) yang mengemukakan bahwa partisipasi anggota merupakan kendala organisasi dalam kelompok PKK di tempat penelitian. Sebanyak 7 orang (28\%) mengemukakan bahwa rapat rutin juga menjadi kendala organisasi. Dapat dilihat dari hasil yang ditemukan di lapangan bahwa partisipasi anggota merupakan modus atau kendala utama dalam organisasi kelompok PKK di tempat penelitian. Beberapa sampel dari responden mengemukakan bahwa saat ini, piket yang sudah dibuat untuk memelihara TOGA jenis kunyit tidak sepenuhnya berjalan dengan baik. Masih ada beberapa orang yang tidak bisa ikut untuk memelihara TOGA jenis kunyit yang sudah dibudidayakan. Salah satu penyebabnya yaitu pekerjaan yang dilakukan oleh responden tidak memungkinkan untuk berperan cukup aktif dalam proses budidaya TOGA kunyit. Sementara para kendala lainnya, yaitu rapat rutin, hanya sebagian kecil saja yang tidak dapat mengikuti rapat rutin tersebut, hal ini dikarenakan waktu dan tempat yang digunakan untuk rapat rutin sudah diagendakan dan disepakati oleh responden sehingga kecil kemungkinan responden tidak dapat hadir dalam rapat rutin tersebut. Kendala yang terjadi ini harus segera diatasi agar petani tetap bertahan dan tidak beralih ke bisnis lain (Saefudin dkk., 2020). Merujuk kepada Rasmikayati dkk. (2019), 
organisasi harus didorong untuk lebih berperan dalam pemasaran hasil panen.

\section{KESIMPULAN DAN SARAN}

Pelaksanaan kegiatan budidaya TOGA di Kelurahan Rancabolang sampai saat ini belum mampu untuk sampai ke tahap produksi untuk dapat dimanfaatkan secara ekonomis. Hal ini dikarenakan sebagian besar hasil panen hanya dimanfaatkan oleh anggota kelompok PKK dan kegiatan panen tidak dilakukan secara rutin ketika sudah sampai masa panen.

Terdapat 4 kendala yang dihadapi masyarakat dalam kegiatan budidaya tanaman Toga berbasis urban farming. Pada aspek kendala budidaya TOGA, lahan yang terbatas menjadi kendala utama dan kendala lainnya yaitu kebutuhan bibit. Pada aspek kendala panen, proses panen yang tidak terjadwal dan tidak rutin menjadi kendala utamanya. Pada aspek pemasaran, jumlah produksi yang masih sedikit menjadi kendala utamanya. Pada aspek organisasi, partisipasi anggota menjadi kendala utama dan kendala lainnya adalah kegiatan rapat rutin untuk membaha Budidaya TOGA.

Kelurahan Rancabolang perlu melakukan rekapitulasi data dalam pengelolaan kebun TOGA di masingmasing RW setiap tahun. Hal ini dikarenakan RW 10 sendiri pada proses pelaksanaanya sudah melakukan kegiatan budidaya TOGA dengan baik akan tetapi pada organisasi Kelompok PKKnya, hanya satu orang saja yang aktif dalam melakukan kegiatan ini.

\section{DAFTAR PUSTAKA}

Amelia, N. R. N., Rochdiani, D., \& Saefudin, B. R. (2020). Analisis Pendapatan Usahatani Jambu Biji Varietas Getas Merah Di Desa Panyingkiran, Kecamatan Panyingkiran, Kabupaten Majalengka. Mimbar Agribisnis: Jurnal Pemikiran Masyarakat Ilmiah Berwawasan Agribisnis, 6(2), 754-764.

Narimawati, U. (2007). Riset manajemen sumber daya manusia. Jakarta: Agung Media.

Nugraha, D. (2018). Pengaruh Lingkungan dan Stress Kerja Terhadap Kinerja Karyawan: Studi Pada PT. Sinar Jaya Riimbawan Asri (Doctoral dissertation, UIN Sunan Gunung Djati Bandung).

Rasmikayati, E., Afriyanti, S., \& Saefudin, B. R. (2020). Keragaan, Potensi dan Kendala pada Usaha Kedai Kopi Di Jatinangor: Kasus pada Belike Coffee Shop dan Balad Coffee Works. Agritekh (Jurnal Agribisnis dan Teknologi Pangan), 1(01), 26-45.

Rasmikayati, E., Azizah, M. N., \& Saefudin, B. R. (2019). Potensi dan Kendala yang Dihadapi Petani Mangga dalam Mengakses Lembaga Pemasaran (Studi Kasus Di Kecamatan Greged Kabupaten 
Cirebon). Paradigma Agribisnis, 2(1).

Rasmikayati, E., Hapsari, H., \& Saefudin,

B. R. (2019). Peningkatan

Pengetahuan dan Ketertarikan

Remaja pada Hidroponik Berbasis

Organik. Jurnal Pengabdian

Kepada Masyarakat, 3(6), 147-151.

Rasmikayati, E., Saefudin, B. R.,

Nadapdap, H. J., \& Awaliyah, F. (2020). Agribusiness Behavior Of Mango Farmers In The District Of Panyingkiran Majalengka Regencybased On Mango Ownership. Sosiohumaniora, 22(2), 206-213.

Rasmikayati, E., Sari, A. F., Kusumo, R. A. B., Saefudin, B. R., \& Syamsiyah, N. (2020). FaktorFaktor Internal Dan Eksternal Yang Berhubungan Dengan Pemilihan Pasar Petani Mangga. Mimbar Agribisnis: Jurnal Pemikiran Masyarakat Ilmiah Berwawasan Agribisnis, 6(2), 936-955.
Riyadi, A. S. (2012). Analisis Efisiensi Persediaan Bahan Baku Industri Abon Lele Karmina di Kabupaten Boyolali.

Saefudin, B. R., Rasmikayati, E., Dwirayani, D., Awaliyah, F., \& Rachmah, A. R. A. (2020). Fenomena Peralihan Usahatani Mangga Ke Padi Di Kecamatan Sedong, Kabupaten Cirebon, Jawa Barat. Paradigma Agribisnis, 2(2).

Saputra, H., Nazir, N., \& Yenrina, R. (2018). Analisis nilai tambah pelaku rantai pasok gambir dengan metode hayami termodifikasi. Jurnal Teknologi Pertanian Andalas, 22(1), 73-78.

Wati, F., Rasmikayati, E., \& Saefudin, B. R. (2020). Analisis Hubungan Karakteristik Anggota Kelompok Tani dengan Penerapan Teknologi Off Season pada Kegiatan Usahatani Mangga di Kecamatan Sedong, Kabupaten Cirebon, Jawa Barat. Jurnal Ekonomi Pertanian dan Agribisnis, 4(4), 715-727. 